DOI: $10.22363 / 2313-2272-2021-21-3-512-519$

\title{
Labor market in the UK in digital era: The gender dimension*
}

\author{
E.A. Mosakova ${ }^{1}$, K. Kizilova ${ }^{2}$ \\ ${ }^{1}$ Lomonosov Moscow State University \\ Leninskye Gory, 1, bldg. 13a, Moscow, Russia, 119991 \\ ${ }^{2}$ Institute for Comparative Survey Research "Eurasia Barometer" \\ Paniglgasse 17/7, Vienna, 1040, Austria \\ (e-mail: lizavetam@mail.ru; ksenniya.kizilova@gmail.com)
}

\begin{abstract}
The article considers gender discrimination in the field of labor relations in the United Kingdom (UK) in the pre-covid period. In the past decades, the Western European countries have made the most significant progress in achieving gender equality in various fields, including labor relations, and became the world leader in this area. However, despite all the efforts of the international community, no country has achieved a full gender equality, and Great Britain is no exception. The authors argue that the British anti-discrimination legislation (before leaving the European Union) was based on international acts and conventions. For a long time, there were acts and laws prohibiting discrimination in the labor market, which seriously hindered the implementation of an effective anti-discrimination policy in the sphere of labor relations. It was not until 2010 that the law on equality was passed to replace all previous laws and regulations and to provide an exhaustive list of criteria for prohibiting discrimination. As a result, Great Britain began to develop a rather strict national anti-discrimination legislation in the field of labor relations. Thus, in the past decades, the UK has been achieving gender equality in the economic sphere at a faster pace than the average European Union country. The study shows a steady decline in the gender wage gap in the UK over the past two decades, which may be considered one of the country's most significant achievements in fighting gender discrimination in the labor market. However, there is still a number of serious challenges: a relatively low female labor force participation and employment rate, a gender wage gap and income gap, horizontal and vertical segregation, a gender gap in postgraduate education, and a significant gender gap in time spent on family responsibilities. Age discrimination presents a special problem in the sphere of labor relations in Great Britain. In the European Union, the first laws prohibiting age discrimination were adopted only in the 2000s, and in the UK - in 2006. This problem still remains extremely acute for the labor market, since age discrimination in the UK ranks third among the most common grounds for discrimination - after gender and disability.
\end{abstract}

Key words: labor market; discrimination; gender; age; GGGI (Global Gender Gap Index); employment; unemployment; wages; segregation; level of education

The issue of discrimination in the sphere of labor relations, namely, the unacceptability of the gender wage gap, was first raised in 1919, when the International Labor Organization (ILO) was founded. And it was not until the end

* (C) E.A. Mosakova, K. Kizilova, 2021

The article was submitted on 21.03.2021. The article was accepted on 04.06.2021. 
of the World War II that this issue reached the international level: the UN Charter of June $26^{\text {th }}, 1945$ contained the requirement of "promoting and encouraging respect for human rights and for fundamental freedoms for all without distinction as to... sex" (Article 1) [12]. However, the term 'discrimination' was not defined, though the Charter became a source of international and national law, a model for many countries.

The definition of discrimination was first given in the special ILO Convention No. 111, the Discrimination (Employment and Occupation) Convention, in 1958: "Any distinction, exclusion or preference made on the basis of race, colour, sex, religion, political opinion, national extraction or social origin, which has the effect of nullifying or impairing equality of opportunity or treatment in employment or occupation" [2]. Scientific works describe a variety of forms and types of discrimination in the labor market, which can occur on the basis of socialdemographic characteristics of the employee, such as gender, age, marital status, parental status, ethnicity, race etc. $[16 ; 18]$.

Two main approaches can be identified to define gender discrimination. According to the first approach, gender discrimination implies any differences, exceptions and limitations on the basis of gender. Thus, the concepts 'gender discrimination' and 'discrimination on the gender basis' are considered to be the same [4]. This approach is typical for such organizations as the ILO, the United Nations (UN) and the European Commission (EC). According to the second approach, the social aspect of gender is distinguished from the biological, i.e., 'gender discrimination' refers to social differences between women and men, which are not limited to the biological sex. The second approach is typical for the World Health Organization (WHO) [5: 31].

In all developed countries, at the national level, a consensus has been reached on gender discrimination - it is prohibited. However, despite all the efforts of the international community for a century, discrimination against women in labor relations still exists, even in the developed countries. To emphasize the importance of gender equality and the need for additional measures to prevent the unfair treatment of women and girls, gender equality was declared one of the 17 goals in the 2030 Sustainable Development Goals (SDG) agenda adopted at the UN Summit in September 2015 in New York. The goal No. 5 of the SDG agenda, accepted by all UN member-states, is "to achieve gender equality and empower all women and girls" [11]. Certainly, the EU has made significant progress in achieving gender equality in various fields, including labor relations, and become a world leader in this area. However, no country has yet achieved the full gender equality. Moreover, in recent years, the pace of achieving this goal has slowed down even in the EU which shows some national differences. Thus, in 2005-2018, gender equality increased faster in $16 \mathrm{EU}$ countries as compared to the all-European growth rate, whereas in other $8 \mathrm{EU}$ countries the growth was slower as compared to the allEuropean figures [15].

There are also substantial differences in the public perception and attitudes between the EU member-states and Great Britain. In the latest wave of the World 
Values Survey (WVS) and the European Values Study (EVS) conducted in 20172020 , respondents were asked to express their opinion about the statement "when jobs are scarce, men should have more right to a job than women". Agreement with this statement means that the respondent has a bias in one's perception of gender equality at the labor market. In the UK, the share of those who agree that men should have more rights to jobs than women decreased dramatically - from 33\% in 1990 to $6 \%$ in 2018. Similar trends can be observed in Germany and France, in which the share of the gender biased opinions declined from $30 \%-32 \%$ to $8 \%-11 \%$. Thus, the indicators of the gender equality perceptions in the UK are among the highest in Europe: the gender equality bias is lower in Iceland (1\%), Denmark (2\%), Finland (4\%) and Netherlands (5\%), and higher in Greece (38\%), Italy (25\%), Poland (23\%) and Spain (11\%). Public perception of the gender equality is an important indicator of the efficiency of gender policies and a factor of success of the state measures, laws and regulations against gender discrimination in the labor market.

The article is based on the data of Russian and international research of gender discrimination in the field of labor relations, on official documents, such as the Global Gender Gap Index 2020 (GGGI), and on the findings of the WVS conducted in 120 countries since 1981 (national representative surveys on values, attitudes and perceptions, including on gender equality at the labor market). Methods for identifying gender discrimination play a special role in its study in the field of labor relations. There are three main approaches: economic and statistical analysis, sociological surveys (of employees and employers) and the 'audit' (several CVs are sent for a vacancy without mentioning the studied parameter - gender or age).

In Great Britain, the anti-discrimination legislation is based on international acts and conventions. In addition, a number of national acts and laws were adopted, which complicates the development of an effective anti-discrimination mechanism. It was not until 2010 that a unified law on was adopted: the Equality Act not only replaced all existing laws and regulations but also provided an exhaustive list of criteria for identifying and prohibiting discriminatory behavior. Thus, the formation of a rather strict anti-discrimination legislation in the British labor market started, which determined the achievement of gender equality at a higher rate than the average for European countries, and the UK has shown a steady decline in the gender wage gap over the past two decades. However, there are still urgent problems to be solved: a relatively low level of women's employment; the gender wage gap and income gap; horizontal and vertical segregation in the labor market; the gender gap in postgraduate education. All this is largely determined by a significant gender gap in the time spent on family responsibilities.

Another important problem in the UK labor market is age discrimination which ranks third among the most common grounds for discrimination after gender and disability. In the UK, the level of discrimination largely depends on age - the highest level of discrimination is typical for younger generations, and then it decreases at older ages. Age discrimination in the labor market is largely due to the late development of relevant legislation - the Equality Act was adopted only in 2006. 
In the UK as an EU member (until January 1, 2021), anti-discrimination regulation in the labor market works at two levels - European and national. The first national anti-discrimination labor law in the UK was adopted in 1970 - the Equal Pay Act proclaimed equal pay for workers doing the same job. In case of violation of the law with evidence, one would go to court. In 1975, the Sex Discrimination Act was adopted - direct and indirect discrimination in the labor market was prohibited [8]. An example of direct discrimination is that a more qualified female candidate gets rejected in favor of a less qualified male candidate. Indirect discrimination implies that the employer creates 'neutral' conditions for all employees including those from the 'protected group'. Moreover, as a part of the development of anti-discrimination labor regulation, the Equal Opportunities Commission was established in 1975 to ensure the strategic law enforcement, mainly for women in the labor market [14].

In 2010, the Equality Act was adopted and unified the existing legislation as a single anti-discrimination law replacing all previous regulations in this area. This act defines discrimination as illegal and sets the procedure for protecting against discrimination [3]. The Equality Act contains a definition of discrimination and an exhaustive list of its prohibited criteria in the field of labor relations - gender, age, marriage and civil partnership, pregnancy and motherhood, religion and belief, disability, race, and sexual orientation.

According to the Section 5 of the Equality Act, the employer is liable for discriminatory acts; however, all reasonable steps to prevent such acts provided, the employer would be exempted from liability. Employers should not post job advertisements only in specialized magazines, for example, for a female audience, since this would be considered indirect discrimination. During the interview, the employer does not have the right to ask 'protected groups' a number of questions, for instance, to ask people with a non-traditional orientation about their marital or parental status. The Equality Act also describes responsibilities of institutions and state authorities in achieving more social equality, and this list expanded significantly as compared to previous laws and regulations. The Equality Act applies to England, Wales and Scotland, but not to Northern Ireland, since it has broad legislative powers and its own laws, including in the field of labor relations. A special place in Great Britain's anti-discrimination policy is given to informing 'protected groups' about anti-discrimination legislation [13] (leaflets and brochures for both employees and employers).

Thus, the British national anti-discrimination legislation develops on the basis of international acts and conventions. Today, the UK has a single unified law in this area with the definitions of relevant concepts and a list of discrimination criteria, including in a section on labor relations. The British anti-discrimination legislation is quite strict for employers; however, there is still gender discrimination in the British labor market.

In terms of gender inequality in the economic sphere, the UK moved from the $9^{\text {th }}$ place in 2006 (when the Global Gender Gap Index was first calculated) to the $21^{\text {st }}$ place in 2019, while the index increased from 0.664 to 0.704 [10]. However, in 
the UK, the pace of achieving gender equality was faster than in the EU on average [4]. For a more detailed study of the British labor market, we should consider the following indicators: labor force participation by gender, employment and unemployment rates by gender, gender income and wage gap, dependence of the gender gap on age, horizontal and vertical segregation, educational level.

Labor force participation rate by gender. In the UK, at the end of 2019, the number of working women was by $11 \%$ lower than the number of male workers 15.34 and 17.1 million respectively [10]. Thus, not all women participate in the labor market, and the number of women who prefer family and do not seek to enter the labor market is growing every year. At the end of 2019, this indicator for women was $72.8 \%$, for men $-82.2 \%$, i.e., the labor force participation rate of women was by $10 \%$ less [10]. Women show such relatively high rates of participation in the labor market despite spending twice as much time on housework: for women, the share of unpaid work per day is $12.65 \%$, for men $-6.87 \%$ [10]. It is noteworthy that since the mid- $20^{\text {th }}$ century, the British government has not interfered in reproductive plans of the citizens due to considering them a private matter for each family. However, British employers provide family employees with full and/or part-time jobs, shorter hours, etc. Moreover, such employees are provided with a larger number of benefits than ensured by the legislation, which contributes to women's combining their professional work with family responsibilities.

Unemployment rate. In 2019, the UK showed almost the same unemployment rate for both genders: $4.16 \%$ for men, $4.03 \%$ for women, i.e., the gender gap was $0.13 \%[10]$.

Gender income gap. At the end of 2019, women's income was by $46 \%$ less [10].

Gender wage gap. Over the past two decades, this indicator has decreased by a third: in $2002-27.3 \%$, in $2008-21.4 \%$, in $2014-20.9 \%$, and in $2019-$ $16.8 \%$ [14]. The UK belongs to the group of countries with a gender wage gap exceeding the European average [10]. Despite the fact that the principle of equal wage was introduced at the international level more than sixty years ago, European women still earn by $15 \%$ less than men [6].

Dependence of the gender wage gap on age. The UK is characterized by a U-shaped model: for employees under 25 years old, this figure is $4.4 \%$; there is a significant increase in the age group of 45-54-year-olds (29.4\%); and a decrease at the retirement age (26.2\%) [19]. The growth of the gap with age is determined by the fact that traditionally the largest gender gap is typical for higher positions (occupied by middle-age workers) with higher wages.

Horizontal segregation. In the pre-covid era, the largest concentration of working women in Great Britain could be found in social sector, service sector, education, trade, medicine and catering. As the EVS/WVS of 2018 shows, $33 \%$ of women worked in governmental or public institutions (19\% of men), while $61 \%$ in private businesses or industries (77\%). The reason of such gender segregation, given the digitalization of the economy, is the information skills gap: for instance, in the sphere of information and communication technologies, the gender gap in relevant skills is a significant barrier for women's career. 
Vertical segregation. Women still work predominantly in low-paid and less prestigious jobs even though having better educational achievements than men. As the EVS/WVS survey of 2018 shows, male and female respondents from the same education groups report different income levels. For example, men with secondary education have an average of 5.9 income level (on a 10-point scale), while women - only 4.9 ; the gap is smaller for those with tertiary education - 6.4 and 6.1 respectively.

The level of education. European and British women are still leaders in terms of education, especially higher education [9. P. 65]. At the end of 2019, the full gender parity was achieved in the UK (index $=1$ ). In 2019, an almost equal number of schoolchildren of both sexes were in primary $(99.4 \%$ of men and $99.6 \%$ of women) and secondary school ( $97.2 \%$ and $97 \%)$ but not in higher education $(69.4 \%$ and $51 \%$ ) [10]. Thus, at higher levels of education, there are significant gender differences, especially in postgraduate education: the share of men with $\mathrm{PhD}$ is $1.19 \%$, while the share of women $-0.82 \%$ [10]. Gender discrimination can be supported by different actors, in various industries, at different job levels, and can start already at the stage of professional training.

Age discrimination is of particular importance in the development of labor relations in Great Britain. In the EU, the first laws prohibiting age discrimination, including in labor relations, were adopted in the 2000s: Council Directive 2000/78/EC of November $27^{\text {th }}, 2000$ introduced the principle of equal rights in employment, in particular, with regard to age. The key feature of the law is that it implied no age limits, which was the United States case. In other words, laws protect workers of all ages from age discrimination in the labor market [17]. The first national law in this area was the Employment Equality (Age) Regulations adopted in 2006. According to them, employers should use such words as 'active' or 'energetic' graduate only for real job requirements [7. P. 255]. Moreover, it was forbidden to deny taking courses by employees over 65 (based on age). The Equality Act was adopted in 2010 and declared the worker's age a prohibited criteria for discrimination in the labor market [3].

Despite the national legislation, age discrimination ranks third among the most common grounds for discrimination - after gender and disability). Of particular note is the shape of the age discrimination curve in the UK labor market: the UK belongs to a group of countries with a high level of discrimination against younger workers [1].

Thus, over the past decades, the UK has achieved gender equality in the economic sphere at a faster pace than the EU on average. In particular, there has been a steady decline in the gender wage gap. Such a significant progress in achieving greater gender equality in the UK labor market is determined by the development of strict anti-discrimination legislation. However, there are still serious problems in the labor market such as the relatively low employment rate of women, gender wage and postgraduate gaps, horizontal and vertical segregation.

\section{References}

[1] Bratt C., Abrams D., Swift H. J., Vauclair C. M., Marques S. Perceived age discrimination across age in Europe: From an ageing society to a society for all ages. Development Psychology. 2018; 54 (1). 
[2] Convention Concerning Discrimination in Respect of Employment and Occupation 1958/ URL: https:/www.un.org/en/development/desa/population/migration/generalassembly/docs/ global compact/ ILO_C_111.pdf.

[3] Equality Act 2010. URL: http://www.legis lation.gov.uk/ukpga/2010/15/section/17.

[4] Gender Equality Report 2020. URL: https://ec.europa.eu/info/policies/justice-and-fundamentalrights/gender-equality en.

[5] Gender mainstreaming for health managers: A practical approach. 2011. URL: https://www.who.int/gender-equity-rights/knowledge/health_manage rs_guide/en.

[6] Gender wage gap, EU, 2019 // https://data.oecd.org/earnwage/gender-wage-gap.htm.

[7] Hardy S., Butler M. European Employment Laws: A Comparative Guide. Ongar; 2011.

[8] Sex Discrimination Act 1975. URL: http://www.legislation.gov.uk/ukpga/1975/65/contents.

[9] Sustainable Development in the European Union. Monitoring Report on Progress towards the SDGs in the EU Context. Luxembourg; 2019.

[10] Global Competitiveness Report 2020. URL. https://reports.weforum.org/global-gender-gapreport-2020.

[11] Transforming our World: 2030 Agenda for Sustainable Development. URL: https://sdgs.un.org/ publications/transforming-our-world-2030-agenda-sustainable-development-17981.

[12] United Nations Charter // https://www.un.org/en/about-us/un-charter.

[13] Bazarov B.N. Legal regulation of discrimination in the field of labor law on the example of the European Union and Great Britain. Tribune of Scientists. 2020; 2. (In Russ.).

[14] Bezsonov V.O. Legal regulation of the prohibition of discrimination in the UK. Epomen. 2020; 44. (In Russ.).

[15] Govorova N.V. The European Union market in the digital age: Gender. Woman in Russian Society. 2020; 3. (In Russ.).

[16] Zajkov D.E. The principle of equal rights and freedoms for men and women: Current state and prospects. Law Journal of the HSE. 2020; 4. (In Russ.).

[17] Ivanova M.A. Demand for older workers and age discrimination: International experience and Russian realities. Voprosy Ekonomiki. 2019; 6. (In Russ.).

[18] Mosakova E.A. Gender discrimination in the labor market of Russia and Japan. Information Society. 2017; 6. (In Russ.).

[19] Nikolaev I.A., Marchenko T.E., Tochilkina O.S. Gender wage gap. Society and Economy. 2018; 2. (In Russ.).

\title{
Рынок труда в Великобритании в цифровую эпоху: гендерное измерение *
}

\author{
Е.А. Мосакова ${ }^{1}$, К. Кизилова ${ }^{2}$ \\ ${ }^{1}$ Московский государственный университет им. М.В. Ломоносова \\ Ленинские горы, 1, стр. 13а, Москва, Россия 119991
}

${ }^{2}$ Институт сравнительных исследований общественного мнения «Евразийский барометр» Панингассе 17/7, Вена, 1040, Австрия

(e-mail: lizavetam@mail.ru; ksenniya.kizilova@gmail.com)

\begin{abstract}
Аннотация. Авторы рассматривают проблему гендерной дискриминации в сфере трудовых отношений в Великобритании в доковидную эпоху. За прошедшие десятилетия западноевропейские страны достигли наиболее значительного за столетие прогресса в
\end{abstract}

* (C) Мосакова Е.А., Кизилова К., 2021

Статья поступила 21.03.2021 г. Статья принята к публикащии 04.06.2021 г. 
обеспечении принципов гендерного равенства в самых разных сферах жизнедеятельности общества, включая трудовые отношения, и стали мировыми лидерами в этой области. Однако, несмотря на все усилия международного сообщества, ни одна страна мира все еще не смогла добиться полного гендерного равенства, и Великобритания не исключение. Авторы считают, что антидискриминационное законодательство Великобритании (разработанное до того, как страна вышла из состава Европейского Союза) основано на международных законодательных актах и конвенциях. В течение длительного времени в Великобритании действовали собственные законы, запрещающие дискриминацию на рынке труда, которые были серьезным препятствием для разработки и внедрения эффективных мер антидискриминационной политики в сфере трудовых отношений. Лишь в 2010 году в Великобритании был принят закон о равенстве, заменивший собой все прежние законодательные правила и содержавший исчерпывающий перечень критериев для определения и запрета дискриминационных практик. В результате Великобритания начала внедрять в сфере трудовых отношений достаточно жесткое антидискриминационное законодательство, что позволило ей в последние несколько десятилетий продвигаться в направлении гендерного равенства в экономике с большей скоростью, чем в среднем характерна для стран Европейского Союза. Исследования подтверждают постепенное сокращение гендерного разрыва в уровне зарплат в Великобритании в последние два десятилетия, что можно считать главным достижением страны в борьбе против гендерной дискриминации на рынке труда. Однако целый ряд проблем сохраняется: относительно низкий уровень представленности женщин на рынке труда, гендерный разрыв в уровне зарплат и доходов, горизонтальная и вертикальная сегрегация, гендерный разрыв в послевузовском образовании и во времени, затрачиваемом на выполнение семейных обязанностей. Возрастная дискриминация - еще одна проблема в сфере трудовых отношений. В Европейском Союзе первые законы, запрещающие возрастную дискриминацию, были приняты только в 2000-е годы, в Великобритании - в 2006 году. Возрастная дискриминация остается актуальной проблемой для рынка труда Великобритании, поскольку возраст - третий по значимости дискриминационный фактор после пола и ограниченных возможностей.

Ключевые слова: рынок труда; дискриминация; гендер; возраст; ИГГР (Индекс глобального гендерного разрыва); занятость; безработица; заработные платы; сегрегация; уровень образования 